\title{
Physico-chemical characterization of some selected soil series of Mymensingh and Jamalpur districts of Bangladesh
}

\author{
P. R. Sheel, M. A. H Chowdhury, M. Ali ${ }^{1}$ and M. A. Mahamud \\ Department of Agricultural Chemistry, Bangladesh Agricultural University, Mymensingh-2202 and ${ }^{1}$ Soil Science \\ Division, BINA, Mymensingh, Bangladesh, E.mail: popi06bau@gmail.com
}

\begin{abstract}
The soil physico-chemical properties have been disturbed due to long continued intensive agricultural practices. Under this situation we are approaching rapidly to a very strong future challenge in sustaining the quality of our soil. This study was conducted to evaluate the physico-chemical properties of the selected soil series. The area covered Mymensingh and Jamalpur districts of Bangladesh. Soil samples were collected randomly from different profiles of Lokdeo, Tarakanda, Silmondi and Melandah soil series during March-May, 2014 and analysed. All soils were acidic and textural classes were sandy loam, silt loam, loam, and clay loam. Organic matter and total $\mathrm{N}$ contents low to very low. Available $\mathrm{S}$ content in the upper layers of most soils were medium to optimum and in the deeper layer low to medium. The exchangeable $\mathrm{K}, \mathrm{Ca}$ and $\mathrm{Na}$ contents were also low. The upper layers of all the locations contained higher amounts of available $\mathrm{Zn}$. The available $\mathrm{Cu}$ and $\mathrm{Fe}$ contents of most soils were very high. The soils of all locations contained very high amount of available Mn except the deeper layers (45-75 cm) of Melandah which contained optimum amount of available $\mathrm{Mn}$. Soil $\mathrm{pH}$ showed negative correlation with total $\mathrm{N}$ and available $\mathrm{S}$. Total $\mathrm{N}$ showed positive correlation with soil $\mathrm{OM}$, available $\mathrm{Cu}$ and available $\mathrm{S}$. There was positive correlation between available S and available Mn.
\end{abstract}

Keywords: Soil Physico-chemical characterization, Mymensingh, Jamalpur

\section{Introduction}

Bangladesh is one of the densely populated developing countries whose economy is mainly based on agriculture. Over the past few decades, changes in various aspects in agriculture such as adoption of high yielding crop varieties along with increased irrigation and fertilization observed in the country. Changes in such factors might have exerted profound effects on the pedogenic processes resulting in the depletion of plant nutrient status of the soils in Bangladesh. Many reports indicate that crop production is declining over time due to depletion of soil fertility. Most farmers tend to exploit the soils rather than maintain a fertility status. Crops are mostly harvested at the root level and straw is used as fuel and fodder. Sometimes the stubbles are grazed or uprooted for fuel, resulting in a low level of organic matter in soil and depletion of nutrients (Islam, 1990). Deficiency of a number of macro and micro nutrients viz. sulphur, zinc, boron and molybdenum etc. in addition to nitrogen, phosphorus and potassium has already been reported from different parts of the country. Such deficiencies might be occurred due to inefficient fertilizer management by the farmers. In a study, Ali et. al. (1997) observed a general trend of organic matter degradation and the need to implement measures to restore the biological productivity of these soils. In Bangladesh, at present the farmers are not getting expected return from their field although they are applying increased amount of various kind of fertilizers. This indicates that the soil physico-chemical properties have been disturbed due to long continued intensive agricultural practices.

Under this situation, we are approaching rapidly to a very strong future challenge in sustaining the quality of our soil and boost the yield to meet the increasing demand of the country. The ever increasing need to increase crop yield per unit area through the balanced use of chemical fertilizers will have to look beyond immediate crop need to build up of soil fertility, so as to provide a solid base to increase crop production in future. It is therefore, also necessary to verify the updated fertilizer recommendation guide in different agro-ecological regions not only for increasing crop productivity but also for improving soil fertility. For evaluating the quality and present fertility status of soil, chemical analysis has got importance because our farmers do not know about the inherent nutrient status of the soil and they use fertilizers injudiciously. In order to minimize these problems, it is very pertinent to evaluate the nutrient status of our soils at the farmer's field level (Ahasan and karim 1998). In view of the above fact, the present study was undertaken to characterize the physico-chemical properties of some soil series of Old Brahmaputra Floodplains of Bangladesh. 


\section{Materials and Methods}

The study area covered Mymensingh and Jamalpur districts of Bangladesh. Soil sample had been collected from Kashimpur, Muktagacha; Barakalar, Gouripur; Gavishimul, Gouripur of Mymensingh districts and Sadar Jamalpur location of Jamalpur districts during March-May, 2014. The representative soil series were identified with the help of Soil Resource Development Institute (SRDI). For better understanding, the sampling sites are described in Table 1. The soil sample were collected from different soil profiles from each location and taken to the laboratory for physical and chemical analyses.

The collected soil samples were dried at room temperature, ground and sieved with a $10 \mathrm{~mm}$ sieve. Then the prepared samples were preserved in polythene bags after labeling for laboratory studies. The soil samples have been analyzed following standard method, viz. particle size distribution by a hydrometer and soil $\mathrm{pH}$ by glass electrode $\mathrm{pH}$ meter, organic carbon by wet oxidation and total nitrogen by kjeldahl method, available $\mathrm{P}$ by Bray and Kurtz method, available $\mathrm{S}$ by turbidimetric method of titration, exchangeable cations e.g. $\mathrm{Ca}, \mathrm{K}$ and $\mathrm{Na}$ were determined by Flame photometer, available $\mathrm{Zn}, \mathrm{Cu}, \mathrm{Fe}$ and $\mathrm{Mn}$ were determined by Atomic Absorption spectrophotometer etc.

Table 1. Description of the soils in terms of morphology and land uses

\begin{tabular}{|c|c|c|c|c|c|}
\hline Soil Series & Location & AEZ & Land Type & Depth (cm) & Present land use \\
\hline Lokdeo & $\begin{array}{l}\text { Kashimpur, } \\
\text { Muktagacha, } \\
\text { Mymensingh }\end{array}$ & $\begin{array}{l}\text { Old Brahmaputra } \\
\text { Floodplain }\end{array}$ & $\begin{array}{l}\text { Medium } \\
\text { Highland }\end{array}$ & $\begin{array}{c}0-10 \\
10-15 \\
15-33 \\
33-53 \\
\end{array}$ & Boro- T.Aman \\
\hline Tarakanda & $\begin{array}{l}\text { Barakalar, } \\
\text { Gouripur, } \\
\text { Mymensingh }\end{array}$ & " & , & $\begin{array}{c}0-9 \\
9-23 \\
23-40\end{array}$ & , \\
\hline Silmondi & $\begin{array}{l}\text { Gavishimul, } \\
\text { Gouripur, } \\
\text { Mymensingh }\end{array}$ & , & ," & $\begin{array}{c}0-12 \\
12-29 \\
29-47\end{array}$ & , \\
\hline Melandah & Sadar, Jamalpur & , & Highland & $\begin{array}{c}0-15 \\
15-30 \\
30-45 \\
45-60 \\
60-75 \\
\end{array}$ & $\begin{array}{l}\text { Mustard-Boro- } \\
\text { T.Aman }\end{array}$ \\
\hline
\end{tabular}

\section{Results and Discussion}

\section{Soil texture}

Table 2 showed the particle size distribution (sand, silt and clay contents) of the soils under study. The textural class of Lokdeo soil series was sandy loam at 0-10 cm, 10-15 cm and 15-33 cm depth. But in 33$53 \mathrm{~cm}$ depth, soil was silt loam. The percentage of sand, silt and clay at four depths ranged from (32.04 to 62.84), (26.06 to 50.09) and (7.16 to 17.87), respectively. The textural class of Tarakanda soil series was loam. Sand silt and clay percentage were ranged from (42.24 to 52.45), (33.43 to 34.00) and (14.12 to 23.76), respectively. The textural classes were sandy loam, loam and sandy loam in $0-12 \mathrm{~cm}, 12-29 \mathrm{~cm}$ and $29-47 \mathrm{~cm}$, respectively. The sand, silt and clay fraction were ranged from (52.54 to 66.35), (22.23 to 26.22) and (11.42 to 21.24), respectively. The textural classes of Melandah soil series were loam, loam, clay loam, sandy loam and loam in 0-15 cm, 15-30 cm, 30-45 cm, 45-60 cm and 60-75 cm respectively. But clay fraction is relatively high in this series. Four textural classes were identified in four locations of Mymensingh and Jamalpur districts. Among them, sandy loam was found in Lokdeo series $(0-33 \mathrm{~cm})$, Silmondi series $(0-12 \mathrm{~cm}$ and $29-47 \mathrm{~cm})$ and Melandah soil series $(45-60 \mathrm{~cm})$. Silt loam was found in Lokdeo series $(33-53 \mathrm{~cm})$. Loam was found in three different depths of Tarakanda series, Silmondi series $(12-29 \mathrm{~cm})$, Melandah soil series $(0-30 \mathrm{~cm}$ and $60-75 \mathrm{~cm})$. Clay loam was found at Melandah soil series $(30-45 \mathrm{~cm})$. These types of variations in sand, silt and clay contents of different depth might be due to movement of the clay and colloidal size particle during percolation from the upper layers to the lower layers. During the rainy season the throwing water carried finer soil particles from the upper surface to lower surface. The soil may be highly productive if it can be managed properly. 


\section{Soil pH}

The results on soil $\mathrm{pH}$ at different soil profiles from four selected areas of Mymensingh and Jamalpur districts are presented in Table 2. The result revealed that soils were acidic. In Lokdeo soil series the soil $\mathrm{pH}$ ranged from 5.33-6.46. In Tarakanda soil series the soil $\mathrm{pH}$ ranged from 4.89-6.21. In Silmondi soil series the soil $\mathrm{pH}$ ranged from 5.32-6.28. In Melandah soil series the soil $\mathrm{pH}$ ranged from 5.82-6.19. In these location the surface soil $(0-10 \mathrm{~cm})$ had low $\mathrm{pH}$ than the deeper layer soil. According to BARC (2012), the soils of these areas were strongly acidic to slightly acidic in reactions. The upper layer of this location was strongly acidic in nature whereas the deeper soils were slightly acidic (Table 2). Bhuiyan (1988), Samad (2007), Hannan (1995) and SRDI (2009) obtained similar results in different soil series of Bangladesh. $\mathrm{pH}$ depends on kinds of basic rocks or parent materials. Rainfall is also a great factor to increase soil acidity. The use of continuous $\mathrm{N}$ fertilizers without the addition of lime contributed to decline this $\mathrm{pH}$. Soil pH increased with the increase of depth. It might be happened due to the removal of basic soil materials like $\mathrm{CaCO}_{3}$ and $\mathrm{MgCO}_{3}$ from upper soil layer with simultaneous accumulation in lower layer through leaching (Prodhan, 2010). From agricultural point of view it was observed that the neutral soils are suitable for crop cultivation. So lime should be applied.

\section{Organic matter content}

The results on OM content of soil at different soil profiles from four selected areas of Mymensingh and Jamalpur districts are presented in Table 2. In Lokdeo, Tarakanda, Silmondi and Melandah soil series the OM content ranged from (0.33 to $1.49 \%)$, (0.89 to $2.02 \%),(0.31$ to $1.15 \%)$ and (0.35 to $1.41 \%)$, respectively. The highest OM content was found at upper soil layer and the lowest OM content was in the deeper layer at all the locations. According to BARC (2012), most of the soils in the series named Lokdeo, Tarakanda, Silmondi and Melandah were low to very low in OM content (Table 2). The upper surface of soil contained higher OM than the lower depths. This is due to addition of OM in surface layer and the presence of compact plough pan in the surface layer. The OM content in general showed a fall with depth which might be perhaps due to the differential decomposition rates of plant and animal residues in successive layer of the profile. This variation also might be possible for addition of OM in the surface layer and presence of compact plough pan in the surface layer. Sood and Kanwar (1986), Bhuiyan (1988) and Mondal (1998) observed similar trend. OM has a close relation with the nutrient availability of soil. At least $2 \%$ organic matter content is suitable for better crop production but all the studied soils did not contain organic matter up to the mark. Soil OM status can be enriched by adding cowdung, compost and through green manuring.

\section{Total N content}

Total $\mathrm{N}$ content in different depths of soil from four selected areas are shown in Table 2. The percentage of total $\mathrm{N}$ content in Lokdeo, Tarakanda, Silmondi and Melandah soil series ranged from (0.034 to $0.11 \%),(0.053$ to $0.15 \%),(0.021$ to $0.074 \%)$ and $(0.042$ to $0.084 \%)$, respectively. The highest total $\mathrm{N}$ content was found at upper soil layer, the lowest was in deeper layer of soil at all the locations. According to BARC (2012), the amount of total N in Lokdeo, Tarakanda, Silmondi and Melandah soil series were low to very low (Table 2). These results were very close to the findings of Portach and Islam (1984) and SRDI (1996). It is apparent from the results that the $\mathrm{N}$ content decreased with the soil depth (Hossain et al, 2003). Total $\mathrm{N}$ contents in these soils might be related to accelerated decomposition of organic matter in the tropical climate, less addition of organic matter, changes in cropping system, the quality and quantity of these elements in flooding water and variation in soil characteristics. Nitrogen content also decreased with decreasing organic matter content of soil. 
Table 2. Textural class, $\mathrm{pH}, \mathrm{OM}$ and total $\mathrm{N}$ contents at different depths of some selected soil series of Mymensingh and Jamalpur districts

\begin{tabular}{l|c|c|c|c|c|c|c|c}
\hline Soil Series & $\begin{array}{c}\text { Depth } \\
\mathbf{( c m )}\end{array}$ & $\begin{array}{c}\text { Sand } \\
\mathbf{( \% )}\end{array}$ & $\begin{array}{c}\text { Silt } \\
\mathbf{( \% )}\end{array}$ & Clay (\%) & $\begin{array}{c}\text { Textural } \\
\text { Class }\end{array}$ & $\mathbf{p H}$ & $\begin{array}{c}\mathbf{O M}^{*} \\
\mathbf{( \% )}\end{array}$ & $\begin{array}{c}\text { Total N } \\
\mathbf{( \% )}\end{array}$ \\
\hline Lokdeo & $0-10$ & 62.84 & 30.00 & 7.16 & Sandy loam & 5.33 & 1.49 & 0.11 \\
& $0-15$ & 58.80 & 26.06 & 15.14 & Sandy loam & 6.11 & 0.78 & 0.07 \\
& $15-33$ & 54.02 & 28.80 & 17.18 & Sandy loam & 6.32 & 0.52 & 0.05 \\
& $33-53$ & 32.04 & 50.09 & 17.87 & Silt loam & 6.46 & 0.33 & 0.034 \\
\hline Tarakanda & $0-9$ & 52.45 & 33.43 & 14.12 & Loam & 4.89 & 2.02 & 0.15 \\
& $9-23$ & 42.24 & 34.00 & 23.76 & Loam & 5.43 & 1.21 & 0.08 \\
& $23-40$ & 46.13 & 34.00 & 19.87 & Loam & 6.21 & 0.89 & 0.053 \\
\hline Silmondi & $0-12$ & 66.35 & 22.23 & 11.42 & Sandy loam & 5.32 & 1.15 & 0.074 \\
& $12-29$ & 52.54 & 26.22 & 21.24 & Loam & 6.27 & 0.64 & 0.056 \\
& $29-47$ & 60.77 & 24.20 & 15.03 & Sandy loam & 6.28 & 0.31 & 0.021 \\
\hline Melandah & $0-15$ & 44.17 & 32.68 & 23.15 & Loam & 5.82 & 1.41 & 0.084 \\
& $15-30$ & 48.89 & 22.01 & 29.10 & Loam & 6.18 & 0.89 & 0.056 \\
& $30-45$ & 36.56 & 30.44 & 33.00 & Clay loam & 6.19 & 0.70 & 0.048 \\
& $45-60$ & 62.34 & 06.23 & 31.43 & Sandy loam & 6.16 & 0.38 & 0.045 \\
& $60-75$ & 42.09 & 22.15 & 35.76 & Loam & 6.12 & 0.35 & 0.042 \\
\hline
\end{tabular}

${ }^{*} \mathrm{OM}=$ Organic Matter

\section{Available $P$ content}

The results on available $P$ content of soils collected from different location of Mymensingh and Jamalpur districts have been presented in Table 3. The available P content at Lokdeo, Tarakanda, Silmondi and Melandah soil series ranged from (10.45 to 31.88), (3.67 to 16.93), (7.62 to 18.91) and (3.65 to 14.33) $\mu \mathrm{g}$ $\mathrm{g}^{-1}$, respectively. In Lokdeo soil series at $0-15 \mathrm{~cm}$ and $15-53 \mathrm{~cm}$ depth of soil, the available $P$ content were medium and high to very high, respectively (BARC, 2012). Available $P$ was very low at $0-9 \mathrm{~cm}$ depth in Tarakanda soil series but it was medium to optimum in deeper layers. In Silmondi series, available P content ranged from low to optimum. The soils of Melandah soil series contained medium amount of available $\mathrm{P}$. The results showed that available $\mathrm{P}$ content decreased with the decrease of soil $\mathrm{pH}$. The low $\mathrm{pH}$ might be responsible for the low level of available P (Table 3). Portch and Islam (1984) reported that $41 \%$ of soils of Bangladesh contained phosphorus below critical level and $35 \%$ below optimum level. The addition of $\mathrm{P}$ fertilizer may benefit the production in the areas where soil contained low level of phosphorus.

\section{Available S content}

The results on available $S$ content of soils collected from different location of Mymensingh and Jamalpur districts have been presented in Table 3. The available S content at Lokdeo, Tarakanda, Silmondi and Melandah soil series ranged from (9.75 to 25.13), (17.99 to 29.56), (21.48 to 7.99) and (10.77 to 24.94) $\mu \mathrm{g} \mathrm{g}^{-1}$, respectively.

According to BARC (2012), the soils of upper layers $(0-15 \mathrm{~cm})$ of Lokdeo series contained optimum to medium amount of available $S$ but the deeper layers $(15-53 \mathrm{~cm})$ contained low amount of available $S$. Tarakanda and Silmondi series contained medium to optimum and low to medium amount of available S, respectively. The upper layers and deeper layer $(30-75 \mathrm{~cm})$ of Melandah soil series contained medium to optimum and low amounts of available S, respectively. The available S content in the soils of upper layers in most of the studied area contained medium to optimum and in the deeper layer low to medium (Table 3). Portch and Islam (1984) reported that $68 \%$ soils of Bangladesh contained S below critical level and $14 \%$ below optimum level. The addition of sulphate fertilizer may benefit the production in these areas. 


\section{Exchangeable K content}

Exchangeable $\mathrm{K}$ content of soils collected from different locations of Mymensingh and Jamalpur districts have been presented in Table 3. The exchangeable $\mathrm{K}$ content at Lokdeo, Tarakanda, Silmondi and Melandah soil series ranged from (0.124 to 0.267$),(0.12$ to 0.132$),(0.087$ to 0.121$)$ and (0.091 to 0.18$)$ $\mathrm{cmol} \mathrm{Kg}^{-1}$, respectively. According to BARC (2012), the exch. $\mathrm{K}$ content was very low to low in most of the soils except the deeper layers $(15-33 \mathrm{~cm})$ of Lokdeo soil series which contained medium amount of exch. K (Table 3). With the increase of \%clay content, exchangeable $\mathrm{K}$ content increase (Portch and Islam, 1984 and Bhuiyan,1988). Continuous cropping without $\mathrm{K}$ application was found to decrease the content of available $\mathrm{K}$ appreciably and increase the influence of $\mathrm{K}$ progressively (Ghosh and Biswas, 1978). So potassic fertilizer should be added in the high deficient areas.

\section{Exchangeable Ca content}

The results on exchangeable $\mathrm{Ca}$ content of soils collected from different location of Mymensingh and Jamalpur districts have been presented in Table 3. The results show that the exchangeable Ca content at Lokdeo, Tarakanda, Silmondi and Melandah soil series ranged from (1.95 to 2.93), (1.03 to 3.63), (0.56 to 2.31) and (1.10 to 2.71) $\mathrm{cmol} \mathrm{Kg}^{-1}$, respectively. According to BARC (2012), the exchangeable Ca was very low to low in most of the soils except Tarakanda series $(0-9 \mathrm{~cm})$ (Table 3). Soil series having low $\mathrm{Ca}$ should be managed properly. The amount of exchangeable $\mathrm{Ca}$ content in different depth did not vary widely but decreased with the soil depth.

\section{Exchangeable Na content}

Data on exchangeable $\mathrm{Na}$ content of soils collected from different location of Mymensingh and Jamalpur districts have been presented in Table 3 . The results show that the exchangeable Na content at Lokdeo, Tarakanda, Silmondi and Melandah soil series ranged from (0.211 to 0.282$),(0.229$ to 0.264$),(0.246$ to $0.334)$ and $(0.194$ to 0.317$) \mathrm{cmol} \mathrm{Kg}^{-1}$, respectively. From the results we found that the studied areas contained low amount of exchangeable $\mathrm{Na}$ as these soils are acidic in reaction. In general, the alkaline and saline soils show superiority on exchangeable Na content over other soils (Akter, 2009).

Table 3. Available and exchangeable macro nutrient contents at different depths of some selected soil series of Mymensingh and Jamalpur districts

\begin{tabular}{|c|c|c|c|c|c|c|}
\hline Soil Series & $\begin{array}{l}\text { Depth } \\
\text { (cm) }\end{array}$ & $\begin{array}{l}\text { Avail. } P \\
\left(\mu g^{-1}\right)\end{array}$ & $\begin{array}{l}\text { Avail. S } \\
\left(\mu \mathrm{g} \mathrm{g}^{-1}\right)\end{array}$ & $\begin{array}{c}\text { Exch. K } \\
\left(\mathrm{cmol} \mathrm{kg}^{-1}\right)\end{array}$ & $\begin{array}{c}\text { Exch. Ca } \\
\left(\mathrm{cmol} \mathrm{kg}^{-1}\right)\end{array}$ & $\begin{array}{c}\text { Exch.Na } \\
\left(\mathrm{cmol} \mathrm{kg}^{-1}\right)\end{array}$ \\
\hline \multirow[t]{4}{*}{ Lokdeo } & $0-10$ & 10.45 & 25.13 & 0.124 & 2.93 & 0.282 \\
\hline & $10-15$ & 12.78 & 15.65 & 0.176 & 2.58 & 0.211 \\
\hline & $15-33$ & 22.67 & 13.23 & 0.189 & 2.73 & 0.246 \\
\hline & $33-53$ & 31.88 & 9.75 & 0.267 & 1.95 & 0.211 \\
\hline \multirow[t]{3}{*}{ Tarakanda } & $0-9$ & 3.67 & 29.56 & 0.12 & 3.63 & 0.229 \\
\hline & $9-23$ & 10.65 & 23.96 & 0.132 & 1.73 & 0.246 \\
\hline & $23-40$ & 16.93 & 17.99 & 0.129 & 1.03 & 0.264 \\
\hline \multirow[t]{3}{*}{ Silmondi } & $0-12$ & 7.62 & 21.48 & 0.087 & 1.25 & 0.334 \\
\hline & $12-29$ & 17.56 & 14.06 & 0.121 & 2.31 & 0.317 \\
\hline & $29-47$ & 18.91 & 7.99 & 0.095 & 0.56 & 0.246 \\
\hline \multirow[t]{5}{*}{ Melandah } & $0-15$ & 11.23 & 24.94 & 0.091 & 2.71 & 0.299 \\
\hline & $15-30$ & 13.65 & 18.82 & 0.093 & 2.53 & 0.317 \\
\hline & $30-45$ & 14.33 & 11.99 & 0.153 & 1.73 & 0.282 \\
\hline & $45-60$ & 12.98 & 12.06 & 0.144 & 1.15 & 0.246 \\
\hline & $60-75$ & 3.65 & 10.77 & 0.180 & 1.10 & 0.194 \\
\hline
\end{tabular}

Avail. $=$ Available, Exch. $=$ Exchangeable 


\section{Available Zn content}

The results on available $\mathrm{Zn}$ content of soils collected from different location of Mymensingh and Jamalpur districts have been presented in Table 4 . It is observed in the table that the available $\mathrm{Zn}$ content at Lokdeo, Tarakanda, Silmondi and Melandah soil series ranged from (2.09 to 4.92), (0.72 to 3.69), (0.80 to 1.81 ) and (1.31 to 2.17) $\mathrm{\mu g} \mathrm{g}^{-1}$, respectively. According to BARC (2012), the upper layers of all the locations contained high to very high amount of available $\mathrm{Zn}$ but the deeper layers contained low to medium amount of available $\mathrm{Zn}$. It is required in small amounts, high yields are impossible without it. Some crops are more responsive to $\mathrm{Zn}$ than others. But excess amount of this nutrient is also harmful for crop production. $\mathrm{Zn}$ is also contained in some fungicides, and may accumulate if these are used persistently. Liming to raise the $\mathrm{pH}$ of the soil may alleviate the problem by reducing the concentrations of plant-available $\mathrm{Zn}$. Large applications of $\mathrm{P}$ fertilizers may also have a beneficial effect on $\mathrm{Zn}$ toxicity (O'Sullivan, 1997).

\section{Available Cu content}

The results on available Cu content of soils collected from different location of Mymensingh and Jamalpur districts have been presented in Table 4 . It is observed in the table that the available $\mathrm{Cu}$ content at Lokdeo, Tarakanda, Silmondi and Melandah soil series ranged from (2.30 to 3.98), (2.74 to 5.65), (1.32 to 2.76$)$ and (0.06 to 2.61) $\mu \mathrm{g} \mathrm{g}^{-1}$, respectively. The soils of all locations contained very high amount of available $\mathrm{Cu}$ except Melandah soil series $(45-75 \mathrm{~cm}$ ) which contained low to very low. Toxic levels of copper $(\mathrm{Cu})$ rarely occur naturally in soils. However, copper may accumulate due to application of sewage sludge, pig slurries or mine slag, or more commonly through persistent use of Cu-containing fungicides or fertilizers.

\section{Available Fe content}

The results on available Fe content of soils collected from different location of Mymensingh and Jamalpur districts have been presented in Table 4. It is observed in the table that the available Fe content at Lokdeo, Tarakanda, Silmondi and Melandah soil series ranged from (100.50 to 127.70), (73.68 to 113.66), (75.51 to 115.52) and (12.06 to 54.66) $\mathrm{gg} \mathrm{g}^{-1}$, respectively. The available Fe in the soils was much higher than the critical limit of $\mathrm{Fe}$ in soil for crop production (BARC 2012). The activity of Fe decreases with the increase in soil $\mathrm{pH}$ (Lindsay, 1974). Liming generally decrease the availability of this nutrient in soil. Iron toxicity is a problem associated primarily with rice crop grown on iron rich low land red and laterite soils. Under these conditions $\mathrm{Fe}^{3+}$ is reduced to $\mathrm{Fe}^{2+}$, which is absorbed by rice plant in larger quantities and causes Fe-toxicity. Other crops grown on such soils also suffer from iron toxicity and consequent yield loss will occur. Predisposing factors for iron toxicity are acidic $\mathrm{pH}$ and poor nutrient status ( $K, P, C a, M g, Z n)$. Application of $K$ at higher doses increases root oxidizing power of rice, which results in oxidation of $\mathrm{Fe}++$ to $\mathrm{Fe}^{3+}$ and exclusion of this ion from uptake. This is evident from increase in intensity of iron oxide coating on rice roots at higher levels of $\mathrm{K}$ application.

\section{Available Mn content}

The results on available $\mathrm{Mn}$ content of soils collected from different location of Mymensingh and Jamalpur districts have been presented in Table 4. It is observed in the table that the available Mn content at Lokdeo, Tarakanda, Silmondi and Melandah soil series ranged from (10.55 to 28.50), (19.30 to 24.12), (4.64 to 21.26) and (2.26 to 23.15) $\mu \mathrm{g} \mathrm{g}^{-1}$, respectively. The soils of all locations contained very high amount of available Mn except the deeper layers $(45-75 \mathrm{~cm}$ ) of Melandah which contained optimum amount of available Mn. It is frequently an abundant constituent of soils, but its low solubility at neutral and alkaline $\mathrm{pH}$ prevents excessive uptake by plants. Manganese is also a component of some fungicides and may accumulate through repeated use of these fungicides, especially to crops grown on sandy soils (O'Sullivan, 1997). As Mn toxicity often results from low soil $\mathrm{pH}$, it can often be corrected by application of lime or dolomite to raise the $\mathrm{pH}$ above about 5.3. Application of additional $\mathrm{K}$ can ameliorate the toxicity of $\mathrm{Mn}$ in rice field (Alam, 2005). 
Sheel et al.

Table 4. Available micronutrient contents at different depths of some selected soil series of Mymensingh and Jamalpur districts

\begin{tabular}{|c|c|c|c|c|c|}
\hline Soil Series & $\begin{array}{l}\text { Depth } \\
\text { (cm) }\end{array}$ & $\begin{array}{l}\text { Avail.Zn } \\
\left(\mu g g^{-1}\right)\end{array}$ & $\begin{array}{l}\text { Avail.Cu } \\
\left(\mu g g^{-1}\right)\end{array}$ & $\begin{array}{l}\text { Avail.Fe } \\
\left(\mu g^{-1}\right)\end{array}$ & $\begin{array}{l}\text { Avail.Mn } \\
\left(\mu g^{-1}\right)\end{array}$ \\
\hline \multirow[t]{4}{*}{ Lokdeo } & $0-10$ & 4.92 & 3.98 & 127.70 & 28.50 \\
\hline & $10-15$ & 3.12 & 3.25 & `122.12 & 22.90 \\
\hline & $15-33$ & 2.66 & 2.92 & 109.10 & 14.98 \\
\hline & $33-53$ & 2.09 & 2.3 & 100.50 & 10.55 \\
\hline \multirow[t]{3}{*}{ Tarakanda } & $0-9$ & 3.69 & 5.65 & 113.66 & 24.12 \\
\hline & $9-23$ & 1.35 & 4.53 & 109.90 & 21.18 \\
\hline & $23-40$ & 0.72 & 2.74 & 73.68 & 19.30 \\
\hline \multirow[t]{3}{*}{ Silmondi } & $0-12$ & 1.81 & 2.76 & 115.52 & 21.26 \\
\hline & $12-29$ & 0.92 & 1.56 & 86.51 & 19.87 \\
\hline & $29-47$ & 0.80 & 1.32 & 75.56 & 4.64 \\
\hline \multirow[t]{5}{*}{ Melandah } & $0-15$ & 2.17 & 2.61 & 54.66 & 23.15 \\
\hline & $15-30$ & 2.03 & 1.76 & 35.41 & 16.02 \\
\hline & $30-45$ & 1.94 & 0.76 & 23.82 & 9.71 \\
\hline & $45-60$ & 1.31 & 0.23 & 13.54 & 2.98 \\
\hline & $60-75$ & 1.71 & 0.06 & 12.06 & 2.26 \\
\hline
\end{tabular}

Avail. $=$ Available

\section{Correlation studies between different soil paramerters}

Soil $\mathrm{pH}$ showed a negative correlation with total $\mathrm{N}$, the value of correlation coefficient was -0.893 with the regression line $y=-0.061 x+0.430($ Fig. $1 \mathrm{~A})$; Soil $\mathrm{pH}$ showed a negative correlation with available $\mathrm{S}$, the value of correlation coefficient was -0.872 with the regression line $y=-12.24 x+89.86$ (Fig. 1B). Soil OM showed a positive correlation with total $\mathrm{N}$, the value of correlation coefficient was 0.953 with the regression line $y=0.061 x+0.011$ (Fig. 1C). Total $N$ content of soil showed a positive correlation with available $S$, the value of correlation coefficient was 0.917 with the regression line $y=186.8 x+5.038$ (Fig. 1D). There was a positive correlation evident between total $\mathrm{N}$ and available $\mathrm{Cu}$ of soil, the value of correlation coefficient was $r=0.806$ with the regression line $y=38.93 x-0.097$ (Fig. 1E). Available $S$ content of soil showed a positive correlation with available $\mathrm{Mn}$, the value of correlation coefficient was 0.826 with the regression line $y=1.038-1.728$ (Fig. 1F). 

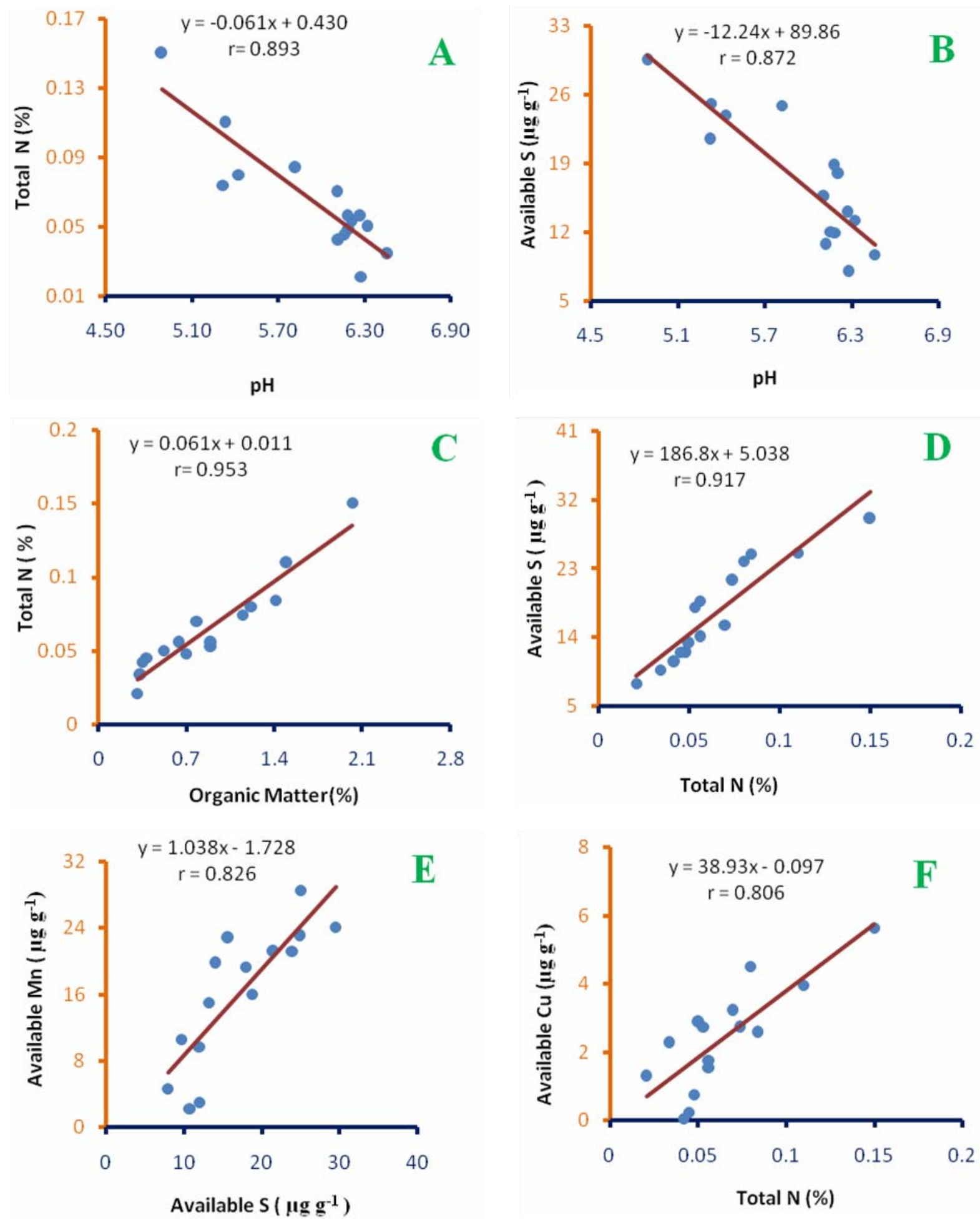

Fig. 1. Correlation between available $P$ and total $N(A)$, total $N$ and available $S$ content (B), total $N$ and exchangeable $\mathrm{Ca}(\mathrm{C})$, total $\mathrm{N}$ and available $\mathrm{Zn}(\mathrm{D})$, total $\mathrm{N}$ and available $\mathrm{Cu}(\mathrm{E})$, total $\mathrm{N}$ and available $\mathrm{Mn}$ content (F) of some selected soil series of Mymensingh and Jamalpur district 


\section{Conclusion}

The textural classes were sandy loam, silty loam, loam and clay loam in the studied areas. The soils in these locations are acidic in nature. Most of the soil contained low to very low organic matter content. Soil $\mathrm{pH}$ showed negative correlation with $\mathrm{OM}$. The total $\mathrm{N}$ content in the soils of the studied area was low to very low. It showed negative correlation with soil $\mathrm{pH}$. The available $\mathrm{P}$ content was medium to high in Lokdeo series. Though other series contained low to optimum amount of available $P$, it showed negative correlation with available $\mathrm{S}$ and total $\mathrm{N}$. The available $\mathrm{S}$ content in the soils of upper layers in most of the studied area were medium to optimum and in the deeper layer low to medium. It showed positive correlation with total $\mathrm{N}$. The exchangeable $\mathrm{K}, \mathrm{Ca}$ and $\mathrm{Na}$ contents were low to very low in most of the soils. The upper layers of all the locations contained high to very high amount of available $\mathrm{Zn}$ compared to the lower layers. It showed positive correlation with total $\mathrm{N}$ and available $\mathrm{S}$. Available $\mathrm{Cu}, \mathrm{Fe}$ and $\mathrm{Mn}$ contents were high to very high in most of the locations. Fe showed negative correlation with total $\mathrm{Mn}$. $\mathrm{Cu}$ and $\mathrm{Mn}$ showed positive correlation with total $\mathrm{N}$. The results suggest that macro nutrient contents of all soils have come down to a level that the soils need external aid in the term of manures or fertilizers to produce higher crop yield.

\section{Acknowledgment}

We express our sincere thanks to all staff members of the Division of Soil Science, BINA, Mymensingh, for their help and cooperation during the research work and are grateful to the Ministry of Science and Technology for awarding NST fellowship.

\section{References}

Alam, S.M.M. 2005.Studies on Some Important Properties of Representative Soil Series from AEZ-5 and AEZ-6, M.S. Thesis, Department Soil Sci., Bangladesh Agricultural University, Mymensingh, Bangladesh. pp. 46-60.

Ahsan, E. and Karim, Z. 1998. Soil Management on Upland Soils of Bangladesh. In: Proceeding of the international conference on the management and fertilization of upland soils in the tropics and sub-tropics. pp. 247-251.

Akter, M. 2009. Soil Quality Evaluation and its Impact on Ecosystem, M. S. Thesis, Department of Agricultural Chemistry, Bangladesh Agricultural University, Mymensingh, Bangladesh.

Ali, M.M., Saheed, S.M., Daisuke, K., Tsugiuki, M., and Toshiyuki, W. 1997. Soil Degradation During the Period 1967-95 in Bangladesh. 1. Carbon and Nitrogen, 2. Selected chemical characters. Soil Science and Plant Nutrition 43(4): 863-878 and $879-890$.

BARC (Bangladesh Agricultural Research Council) 2012: Fertilizer Recommendation Guide-2012. Soils. Pub. No. 41. Bangladesh Agricultural Research Council, Farmgate, Dhaka. pp. 251-260.

Bhuiyan, N.I. 1988. Coordinated project on potassium studies Progress report (1987-88). BARI, Joydevpur, Gazipur. pp. 1-45.

Black, C.A. 1965. Methods of Soil Analysis, Part I, Agronomy Monographs 9. ASA Madison, Wisconsin, USA.

Bray, R.H. and Kurtz, L.T. 1945. Determination of Total, Organic and Available Forms of Phosphorous in Soils, Soil Science 59: 3945.

Ghosh, A.B. and Biswas, C.R. 1978. Proc. Int. potassium symp. Potash Res. Inst. New Delhi. pp. 379-390.

Hannan, M.A. 1995. Structure and related physical properties of some soils of Bangladesh, MS Thesis. Department of Soil Science, Bangladesh Agrilultural University, Mymensingh, Bangladesh. pp. 138-152.

Hossain, A., Hossain, A.K.M.M., Rahman, M.S., Rahman, M.M., Chowdhury, M.A.H. and Khan, M.S.H. 2003. Effect of tillage practices on soil properties under different cropping patters. J. Sci. Technol. 1: 43-48.

Jackson, M.L. 1962. Soil Chemical Analysis. Prentice Hall Inc., Englewood Cliffe., N. J.

Lindsey, W.L. 1974. Role of chelation in Micronutrient availability. P. 507-524. In: EW Carson (Editors), The plant root and its environment. The University Press of Virginia, Charlottesville.

Mondal, M.Y.A. 1998. Studies on the physical properties of BAU Farm soil, MS Thesis. Department of Soil Science, Bangladesh Agricultural University, Mymensingh. pp. 1-106.

O'Sullivan, J.N., Asher, C.J. and Blamey, F.P.C. 1997. Nutrient Disorders of Sweet Potato. ACIAR Monograph No. 48, Australian Centre for International Agricultural Research, Canberra. pp. 136.

Portch, S. and Islam, M.S. 1984. Nutrient status of some of the more important agricultural soils of Bangladesh. Int. proc. of the Int. symp. on soil test crop response correlation studies, BARC, Dhaka. pp. 97-106. 
Prodhan, R. 2010. Study on the Nutrient Status of Selected Major Soil Series of Old Himalayan Piedmont Plain (AEZ 1) of Bangladesh, MS Thesis, Department of Agricultural Chemistry, Bangladesh Agricultural University, Mymensingh-2202.

Samad, M.A. 2007. Evaluation of physico-chemical characteristics of soils in three soil series of Bangladesh, MS Thesis. Department of Soil Science, Bangladesh Agricultural University, Mymensingh, Bangladesh. pp 1-58.

Sood, R.D. and Kanwar, B.S. 1986. Distribution of organic and total phosphorus in some soil profiles of different agro-climate zones of Himalchal paradesh. J. of Indian Soc. Soil Sci. 34 (30): 404-406.

SRDI, 1996. Land and Soil Resources Utilization (in Begali). Thana Nirdeshika Series-Shibganj thana. Soil Resources Development Institute, Dhaka, Bangladesh. pp. 46-52.

SRDI, 2009. Land and Soil Resources Utilization Guide (in Bengali). Upazila Nirdeshika series, Muktagacha Upazila, SRDI, Dhaka, Bangladesh. pp. 66-68.

Walkley, A and I.A. Black 1934. An examination of the degtjareff method for determining soil organic matter and proposed modification of the chromic acid titration method Soil Sci. 37:29-38. 